\title{
Review of E-Commerce Business in India
}

\author{
Krishnalatha Vathalulua, Dr. Gajraj Singh Ahirwar ${ }^{\text {b }}$ \\ a Research Scholar, Dept. of Commerce, \\ Sri Satya Sai University of Technology \& Medical Sciences, Sehore, Bhopal Indore Road, Madhya Pradesh, India \\ besearch Guide, Dept. of Commerce, \\ Sri Satya Sai University of Technology \& Medical Sciences, Sehore, Bhopal Indore Road, Madhya Pradesh, India
}

Article History: Received: 11 January 2021; Accepted: 27 February 2021; Published online: 5 April 2021

\begin{abstract}
E-Commerce is growing step by step in both B-to-B and B-to-C context. Retailing industry including Fashion Retail and Grocery retailing have gotten on to the trend and have begun to offer E exchanging or Online Shopping. In the early 1990s we saw Companies setting up websites with very little understanding of E Commerce and Consumer behavior. E commerce as a model is entirely unexpected from conventional shopping in all respect. All Companies have quick realized the require to have E commerce strategy separately yet as a piece of overall Retail Strategy. Retail Strategy involves anticipating the business development keeping in view the current market trends, opportunities just as threats and building a strategic arrangement that helps the Company deal with all these external factors and stay on course to reach its objectives. Further the Retail business strategy is concerned with identifying the markets to be in, building the product portfolio and band width coupled with brand situating and the different elements of brand perceivability and in store advancements etc. Business operations are more or less norm and proven models that are adapted as best practices.
\end{abstract}

\section{Introduction}

The internet provides new ways for customers to look for their needs. Internet technology is available everywhere worldwide and utilizing the internet for data is already the number one reason customers' state for being online. Internet technology permits products and services to be offered on a scale never possible before: a potential worldwide market with a variety of choices that is essentially impractical with limited actual floor space (Cunningham, 2000). E-retailers would now be able to serve their customers twenty-four hours per day with variety of products and services at reduced price (Walsh and Godfrey, 2000). In spite of the fact that there are potential business benefits emerging from the usage of Internet, successful e-retailing actually face numerous challenges, for example, improved customer service, increased competition and increased expense of website and content management.

While these remain a significant managerial challenge, there is additionally a changing wave of customers developing expectation for persistent improved products and service offering. Retail businesses ought to therefore take advantage of internet opportunities and construct enduring customer-retailer relationship for a sustained customer dedication. More personalized service that satisfies customers need can be developed and deployed into e-commerce environment.

Research and development in the data and interchanges technologies (ICT) sector is consistently making new headways and developing new products that render previous ones obsolete, and attempting to keep up with the ever-changing environment is an increasing concern of developing countries. There is presently sufficient and developing evidence that enterprises acquire generously from e-business. Quick productivity development in industrialized countries has been largely attributed to the widespread utilization of ICT, creating a huge number of new positions and billions of dollars in investment funds. The advancement of the internet and the consequent development of electronic commerce have resulted in a powerful operating environment where business transactions are conducted over the internet. Internet transactions are a basic element of e-commerce as business transactions, for example, buying and selling of products and services and correspondence are conducted over the internet (Janita and Chong, 2013). As indicated by Lawrence and Tar (2010), internet transactions provide great opportunities for businesses in terms of accessing markets across the globe and a driver of the economy a developing country, for example, Kenya. The appropriation of internet transactions has altogether supported the development of businesses and holds a promise in the reduction of expenses and improvements in the operational efficiency. Due to internet transactions, relationships between the business and its customers have become closer. Electronic commerce has altogether increased interactivity inside the economy and this extends even to little firms that hope to reach out to the entire world. Online transactions have increased the capacity of people to communicate just as to complete business in practically any area and whenever and this has eroded the geographic just as economic boundaries.

\section{Literature Review}

Jawahar Babu et al as name suggest, is zeroing in on the customer retention. Gone are those occasions when once customer is won, he will be steadfast for the duration of his life. Presently a day's customer must be satisfied on every interaction. Due to this retail has become more customer centric at this point. Likewise it is generally said that retained customers tend to have higher level of perceived nature of service. It is quite evident that cost of procurement of customer is more than cost of retention of the customer. All efforts are directed to 
retain already acquired customers and relationship marketing has proved to be one of the key devices in same. Through membership approach, customer information is acquired with respect to his/her interest and demand structure. This data is linked with customer information which is then used for designing personalized mission. M A Shaikh et al deals with the Organized Retail and strategies to enhance the organized sale at shopping centers. Overall retail is filling very quick in India with significant increase seen from Organized retail. Shopping centers are one of the most attractive channels for Organized retail what started with 3 shopping centers in 1999 to 190 out of 2010 and current scenario where number is around 280. During blast time numerous developers entered the market with building shopping centers with no arranging, market research, marketing strategy etc. which resulted into lower performance than what was expected. The fundamental problems faced by a large portion of the shopping centers are empty shops, low foot-fall, some shopping centers are already closed down. On other hand some of the firmly positioned shopping centers are performing well. This research paper is based on the examination conducted about the situating strategies. While describing the current retail scenario, creators have pointed out that overall, store-based retailing has developed by $81.2 \%$ in the period 2006-11. In same period of 2006 to 2011, sales from Non-store retail shoot-up by $200 \%$. The retail sector as a whole reported development of $82 \%$ in this period. The retail purchase varies across area. Metropolitan area denotes the purchase of $65 \%$ in organized retail while $28 \%$ in unorganized retail. Semi metropolitan area marks $23 \%$ purchase in Organized while 53\% in unorganized and in country market, 13\% purchase comes from Organized retail while $19 \%$ comes from unorganized.

Raghunath et al concluded that at first, new internet users would be reluctant to direct any sort of business online, refering to security reasons as their principle concern. To increase consumer appropriation of eservices, the source of consumer disarray, apprehension and danger need to be identified, understood and elevated. ECommerce provides tremendous opportunities in different areas yet it requires careful application for consumer protection issues.

Madhukar Sarode in his paper concluded that ecommerce is future of shopping and hole has been reduced between manufacturer and consumer due to e-commerce. There is huge scope for e-commerce in India yet due to weak cyber law, people are confronting challenges in India.

Saxena, 2015 in her paper concluded that e-commerce assumes an essential part in Indian society. It assumes a significant part in overhauling and developing the Indian economic system. It provides backing to little and medium enterprises to prosper their business. E-commerce likewise faces some challenges like absence of cyber laws and absence of computer education etc.

Ramchandani, 2016 in her paper concluded that the retail e-commerce sales in 2015 as a percentage of absolute retail sales in India accounted for approximately $0.9 \%$ of all retail sales in India. However this figure is expected to fill in near future and is estimated to reach $1.4 \%$ in 2018 . E-Commerce has greatly impacted the business of actual retailers' especially little retailers. International e-retailers are giving a solid competition to domestic ones. However actual retailers actually have a very decent remaining in the Indian market as Indian consumers generally like to inspect the goods before making any purchase.

\section{Present Scenario of E-Commerce}

E-Commerce in India is as yet in a developing stage, however it offer tremendous opportunities for developing countries like India. The e-commerce sector in India started their operations late nineties among business to business users (B2B). Business to Consumers (B2C) e-commerce started in 1996 as wedding gateways. The expense and the speed of internet was the restricting element for their development at that time. The first ECommerce website in Quite a while was rediff.com, which was one of the most trafficked entrances for the two Indians and non - residents Indians. Most recent five years have seen a rise in the number of companies enabling e-commerce technologies and the internet in India. Significant Indian entrance sites have additionally shifted towards e-commerce instead of depending on advertisement revenues. Today E-Commerce has become an integral piece of our society. There are websites giving quite a few goods and services. These websites provide practically all categories of goods and services on a single site. These sites target the buyers of every possible product or service. These websites are known as Multi Product E-Commerce Sites. There are additionally Single Product E-Commerce Sites, which deal in specialized field as it were. Technology is changing the method of shopping. Out of the all out internet users in India, 60\% visit e-commerce sites. Favored demographics and developing internet users' base helped in adding the development. Development appeared by Indian players like Flipkart, India Times, Snapdeal etc. what's more, huge investors' interest around these companies showed the immense potentials of the market.

\section{Future of E-Commerce in India}

The E-Commerce sector in India is filling quickly in India. The internet users' base in India may in any case be mere 400 millions which is considerably less as compared to developed countries of the world, yet it is expanding step by step. The accelerating development of e-commerce in India is due to internet penetration and easily available advanced mobile phones. Furthermore the favorable demographics and government effort of 
digitalization is likewise pushing the development of e-commerce sector in India. Retail sector is one of the largest developing sectors in India at present, which is expected to develop in future with an increasing rate.

\section{Difficulties of E-Commerce in India Poor Internet Facilities}

Internet is considered the backbone of the e-commerce. But the penetration of internet facilities in India especially in rural area is very less. Speed of Internet is also the major challenge in our country. No doubt we are moving towards $4 \mathrm{G}$ internet services but still a lot has to be done.

\section{Feeling Unsecure}

Feeling unsecure by customer is one of the major and continuing challenges for e-commerce in our country. Customers have to be confident about the integrity of the e-dealers and payment process before making any purchase order online. Risk of hacking and cyber crimes are also there. Privacy has also become a major concern for consumers with identity theft and impersonation. Security challenges are not restricted to consumers only in e-commerce, corporate firms also face security challenge as their vital information, records and reputation is at stake.

\section{Logistic and Supply Chain}

Coordinations and inventory network has been the significant challenge to the e-commerce companies. The vast majority of the populace in India lives in villages. To reach the consumer in the village is a major challenge. The e-commerce companies' needs to invest more on setting up warehouse and joining more suppliers the nation over to ensure customers get order delivered by nearest suppliers.

\section{Cash on Delivery}

Cash on delivery is enormous problem for e-commerce companies. In the era of advanced payments, cash on delivery is as yet the most favored mode of payment used by the consumers. This mode is very expensive for ecommerce companies. Sometime courier companies take 30-40 days to return the cash collected from customers to dealers. In the event that the customer return the product than it becomes very expensive for the organization as the organization pay two way courier charges.

\section{High Competition}

There is a relentless competition among the player in the e-commerce market. With intense competition, the productivity of the of the companies decreases as they use aggressive estimating strategy and offer huge discounts and commissions.

\section{Tax Structure}

Tax structure is another factor for lesser development of e-commerce sector in India in contrast with other developed countries like USA and UK. In India there are different types of taxes and these taxes create bookkeeping problems to online business. Some states are even charging separate duty on e-commerce transactions. Government has implemented the GST Act, which is expected to solve this problem to great extent. Absence of cyber laws

Absence of cyber laws to regulate the online business transactions is another bottleneck to e-commerce in India. The new technology has created huge legal uncertainty in our country. The existing Consumer Protection Act 1986 needs to be amended to update and widen the scope of the Act.

\section{Conclusion}

E-Commerce has made the shopping easy. The E-Commerce Industry in India is developing quickly despites many challenge. E-commerce industry is one of the largest developing industries in India at present. The sale of ecommerce industry is expected to develop by just about 4 times by 2021 than the sales of 2015. This unprecedented development in E-Commerce is due to increase in PDAs and internet users, 3G/4G internet services, awareness out in the open, government initiative of digitalisation, advanced transportation and payment choices, entry of foreign e-business players etc. Government should take steps to provide a proper legal framework so that hurdles in the development of e-commerce are reduced to least.

\section{REFERENCES}

1. Jawahar Babu, D. K., \& Masthanvali, K. S. (2017). Role of Customer Retention Strategies in Retailing Sector. International Journal of Research in Commerce \& Management, 25-26.

2. Shaikh, M. A., \& Shinde, D. D. (2017). Strategies Implemented In Organized Retail Sector. International Journal of Research in Commerce \& Management, 24-27.

3. Indian retail: The next growth story . $(2014,117)$. Retrieved 09 09, 2016, from KPMG.in: https://home.kpmg.com/in/en/home/insights/2014/11/indianretail.html 
4. Kusuma, B., Durga Prasad, N., \& Srinivasa Rao, M. (2013). A Study on Organized Retailing and Its Challenges and Retail Customer Services. Innovative Journal of Business and Management, 97-102.

5. Jain, V. (2016). Challenges for Organized Retailing in India. International Journal of Research In Commerce \& Management, 45-47.

6. eMarketer, "Global Ecommerce 2019," Andrew Lipsman, 2019. [Online]. Available: https://www.emarketer.com/content/global-ecommerce-2019. [Accessed: 09-Nov-2019].

7. Vengatesan, K. et al. "An approach of sales prediction system of customers using data analytics techniques". Advances in Mathematics: Scientific Journal 9. 7(2020): 5049-5056.

8. A. K. Y. Tang, "A systematic literature review and analysis on mobile apps in m-commerce: Implications for future research," Electron. Commer. Res. Appl., 2019.

9. Crunchbase, "Closed Europe E-Commerce Companies," 2019. [Online]. Available: https://www.crunchbase.com/hub/closed-europe-commerce-companies\#sectionoverview\%0D. [Accessed: 19-Nov-2019

10. Y. Tian and C. Stewart, "History of E-Commerce," in Electronic Commerce, IGI Global, 2011, pp. 1-8.

11. Steve Olenski, "The Evolution of E-commerce," Forbes.com, 2015. [Online]. Available: https://www.forbes.com/sites/steveolenski/2015/12/29/the-evolutionof-ecommerce/\#3e7d935f7145

12. L. Xiao, F. Guo, F. Yu, and S. Liu, "The effects of online shopping context cues on consumers' purchase intention for cross-border E-Commerce sustainability," Sustain., 2019.

13. C. P. Chen, H. M. Lai, and C. Y. Ho, "Why do teachers continue to use teaching blogs? the roles of perceived voluntariness and habit," Comput. Educ., 2015.

14. T. Haryanti, "Document Management System and Reminder using SMS Gateway," IOP Conf. Ser., vol. 469, no. Earth and Environmental Science, pp. 1-7, 2020. 